\title{
Bulnesia sarmientoi Supercritical Fluid Extract Exhibits Necroptotic Effects and Anti-Metastatic Activity on Lung Cancer Cells
}

\author{
Heng-Long Wang ${ }^{1}$, Jung-Che Chang ${ }^{1}$, Li-Wen Fang ${ }^{2}$, Hsia-Fen Hsu ${ }^{2}$, Li-Chiun Lee ${ }^{2}$, \\ Jyh-Ferng Yang ${ }^{3}$, Ming-Tsai Liang ${ }^{3}$, Pei-Chi Hsiao ${ }^{4}$, Chao-Ping Wang ${ }^{5}$, Shih-Wei Wang ${ }^{6}$, \\ Chi-Chang Chang $7, *,+$ and Jer-Yiing Houng $2,3, *,+(\mathbb{D}$ \\ 1 Department of Life Sciences, National University of Kaohsiung, Kaohsiung 81148, Taiwan; \\ hlwang@nuk.edu.tw (H.-L.W.); jungche2004@yahoo.com.tw (J.-C.C.) \\ 2 Department of Nutrition, I-Shou University, Kaohsiung 82445, Taiwan; fanglw@isu.edu.tw (L.-W.F.); \\ fen153848@gmail.com (H.-F.H.); edman@isu.edu.tw (L.-C.L.) \\ 3 Graduate Institute of Biotechnology and Chemical Engineering, I-Shou University, Kaohsiung 84001, \\ Taiwan; jfyang@isu.edu.tw (J.-F.Y.); mtliang@isu.edu.tw (M.-T.L.) \\ 4 Metal Industries Research \& Development Centre, Kaohsiung 81160, Taiwan; peg3319@gmail.com \\ 5 Divisions of Cardiology, E-Da Hospital/I-Shou University, Kaohsiung 82445, Taiwan; ed100232@edah.org.tw \\ 6 Division of Allergy, Immunology, and Rheumatology, Department of Internal Medicine, \\ E-Da Hospital/I-Shou University, Kaohsiung 82445, Taiwan; shihwei8888@gmail.com \\ 7 Department of Obstetrics \& Gynecology, E-Da Hospital/I-Shou University, Kaohsiung 82445, Taiwan \\ * Correspondence: ed101779@edah.org.tw (C.-C.C.); jyhoung@isu.edu.tw (J.-Y.H.); \\ Tel.: +886-7-6151100 (ext. 7915) (J.-Y.H.) \\ + These authors contributed equally to this work.
}

Received: 20 November 2018; Accepted: 11 December 2018; Published: 13 December 2018

\begin{abstract}
Bulnesia sarmientoi (BS) has long been used as an analgesic, wound-healing and anti-inflammatory medicinal plant. The aqueous extract of its bark has been demonstrated to have anti-cancer activity. This study investigated the anti-proliferative and anti-metastatic effects of BS supercritical fluid extract (BSE) on the A549 and H661 lung cancer cell lines. The cytotoxicity on cancer cells was assessed by an MTT assay. After $72 \mathrm{~h}$ treatment of A549 and H661 cells, the $\mathrm{IC}_{50}$ values were 18.1 and $24.7 \mu \mathrm{g} / \mathrm{mL}$, respectively. The cytotoxicity on MRC-5 normal cells was relatively lower $\left(\mathrm{IC}_{50}=61.1 \mu \mathrm{g} / \mathrm{mL}\right)$. BSE arrested lung cancer cells at the $S$ and $\mathrm{G}_{2} / \mathrm{M}$ growth phase. Necrosis of A549 and H661 cells was detected by flow cytometry with Annexin V-FITC/PI double staining. Moreover, the cytotoxic effect of BSE on cancer cells was significantly reverted by Nec-1 pretreatment, and BSE induced TNF- $\alpha$ and RIP-1 expression in the absence of caspase- 8 activity. These evidences further support that BSE exhibited necroptotic effects on lung cancer cells. By wound healing and Boyden chamber assays, the inhibitory effects of BSE on the migration and invasion of lung cancer cells were elucidated. Furthermore, the chemical composition of BSE was examined by gas chromatography-mass analysis where ten constituents of BSE were identified. $\alpha$-Guaiene, $(-)$-guaiol and $\beta$-caryophyllene are responsible for most of the cytotoxic activity of BSE against these two cancer cell lines. Since BSE possesses significant cytotoxicity and anti-metastatic activity on A549 and H661 cells, it may serve as a potential target for the treatment of lung cancer.
\end{abstract}

Keywords: Bulnesia sarmientoi; supercritical fluid extraction; human lung cancer cells; necroptosis; migration and invasion; chemical ingredient analysis 


\section{Introduction}

Lung cancer is one of the leading causes of death in the world, responsible for more than 1.5 million deaths worldwide annually [1]. There are two major subtypes of lung cancer, non-small-cell lung cancer (NSCLC) and small-cell lung cancer (SCLC). NSCLC accounts for approximately 80-85\% of lung cancer cases. The high mortality rate of this disease may be related to the obscurity of the symptoms and its high metastasis rate. It is estimated around $57 \%$ of all lung cancers are metastatic in nature and can spread to various tissues and organs [2,3]. Various methods, such as chemotherapy, surgery, and radiation therapy, have been used to treat lung cancer patients. However, more effective therapies still need to be developed for curing the cancer, especially the treatment for the advanced stages of cancer.

Traditionally, two types of cell death under drug treatment are generally recognized: apoptosis and necrosis. Apoptosis is regarded as one form of programmed cell death, whereas necrosis is regarded as an uncontrolled and unregulated type of cell death. Recently, accumulating evidences have shown that necrosis can also be induced and proceed in a regular manner, which is a caspase-independent form of regulated cell death. This type of necrosis is called "programmed necrosis" or "necroptosis" [4]. For the necroptosis, upon stimulation of Fas/TNF receptor family to trigger extrinsic apoptotic signal, cells exhibit the morphology like necrotic cell death in the absence of caspase activity, and then could transduce necroptosis signal. In addition, the death of these necrotic cells was regulated by unique signaling pathway, dependent on receptor-interacting protein kinase 1 (RIP-1) and/or RIP-3 and specifically inhibited by the small molecule, necrostatin-1 (Nec-1) [5]. Necroptosis was found to associate with pathogenic effect on ischemic brain injury, myocardial infarction and neurodegeneration [6-8]. Drug resistance contributes to the high mortality of cancer, i.e., cancer cells can escape from apoptosis caused by chemotherapeutic drugs and this makes them resistant to chemotherapy. Several studies have revealed that necroptosis would accelerate the death of cancer cells by increasing the sensitivity of tumor cell to chemotherapy drugs [9-11]. Therefore, necroptosis provides an alternative process to enhance the sensitivity of cancer cells to chemotherapeutic agents, especially for the cases where the cancer cells are resistant to apoptosis. These properties make necroptosis a new target to eliminate cancer cells when caspases are inhibited or defective [12,13].

Metastasis is a critical step in cancer progression and is the leading cause of cancer-related deaths in human. Tumor metastasis is a complex multistep process, including tumor angiogenesis, cell migration, cell attachment, degradation of extracellular matrix (ECM), invasion and proliferation. Through these events, cancer cells spread primarily through the thin wall of the ECM into the blood vessels or lymphatic circulation system to colonize distant organs, and ultimately resulting in distant metastasis [14-16].

Some plants were reported to have anti-lung cancer effects, including Podophyllum peltatum, Taxus brevifolia Nutt., Catharanthus roseus, and Camptotheca acuminata. Some of their bioactive compounds had been developed as chemotherapeutic drugs, such as podophyllotoxin derivatives [17,18], taxol [19], vinca alkaloids [20] and camptothecins [21]. Most of them exhibit apoptotic effects on tumors, while some agents trigger necroptosis in cancer cells [22-26]. Shikonin was the first compound that was reported to have the ability to induce necroptosis [27]. Subsequently, shikonin and its analogs were reported successively to have high cytotoxicity on cancer cells, as well as the ability to avoid drug resistance [28-31]. Furthermore, shikonin could reduce the lung metastasis of osteosarcoma by inducing necroptosis [29].

Supercritical fluid extraction (SFE), generally performed by carbon dioxide $\left(\mathrm{CO}_{2}\right)$, has been widely recognized as a green sample preparation technique and has several advantages of non-toxicity, efficiency, high separation selectivity and environmental friendliness, while it avoids thermal degradation and can be recyclable. Especially, due to the lipophilic nature of $\mathrm{CO}_{2}$, SFE is very suitable for the extraction of non-polar or moderately polar ingredients. Therefore, the use of SFE to extract plants is rapidly increasing [32-34].

Bulnesia sarmientoi (BS, Palo Santo), an endemic tree in the Gran Chaco area around Argentina, Bolivia, Brazil, and Paraguay borders, belongs to the Zygophyllaceae family, which is frequently 
used to produce wood furniture, handicrafts, Buddha tables, and flooring. The wood waste of BS is often used to extract essential oils, which have the balmy rose or violet aroma, and have been used in perfumery and aromatherapy [35]. Besides this, BS has been used as a traditional medicine in analgesic, wound healing, anti-inflammation, antioxidant, bactericidal activities, to improve serum lipid profiles and treat gastrointestinal problems [35,36]. Aqueous extract of BS (aqBSE) exhibited anti-platelet activity and thrombus formation via MAP kinase inhibition [37]. BS has also shown anti-tumor activity. The aqBSE could induce apoptosis of A549 lung cancer cells via p53 induction and decrease the tumor size in subcutaneous sarcoma 180 tumor-bearing nude mice [38]. A similar apoptotic effect of aqBSE on lung cancer H460 cells was also reported [39]. A further study demonstrated that (-)-epicatechin isolated from aqBSE could enhance the apoptosis of SW480 human colon cancer cells by Bax and p53 induction and Bcl-2 down-regulation [40]. Instead of the aqueous extract, this study evaluates the anti-cancer potential of BS SFE extract (BSE) on lung cancer cells. The inhibitory effects of BSE on cell proliferation, migration and invasion of lung cancer A549 and H661 cells were investigated. Furthermore, the cell necroptosis induced by BSE was also elucidated.

\section{Results and Discussion}

\subsection{Effects of BSE on Anti-Proliferation of Human Lung Cancer Cells}

The cytotoxicities of BSE on A549 and H661 human lung cancer cells and human fetal lung fibroblast MRC-5 normal cells are shown in Figure 1. The treatments were performed at different doses for 24, 48 and $72 \mathrm{~h}$, respectively. From the data shown in the figure, BSE exhibited the cytotoxicities on each of these three cell lines in a dose-dependent manner. On the other hand, Table 1 shows that the longer the treatment time, the greater the cytotoxicity. Among these three cell lines, BSE exhibited a much lower toxicity to MRC-5 normal cells. When comparing to the clinical anti-cancer drug cisplatin, BSE and cisplatin had similar cytotoxicity on lung cancer cells, but BSE appeared less toxic to MRC-5 normal cells than cisplatin. It is worth noting that cisplatin had higher toxicity to the normal lung cells than the lung cancer cells.
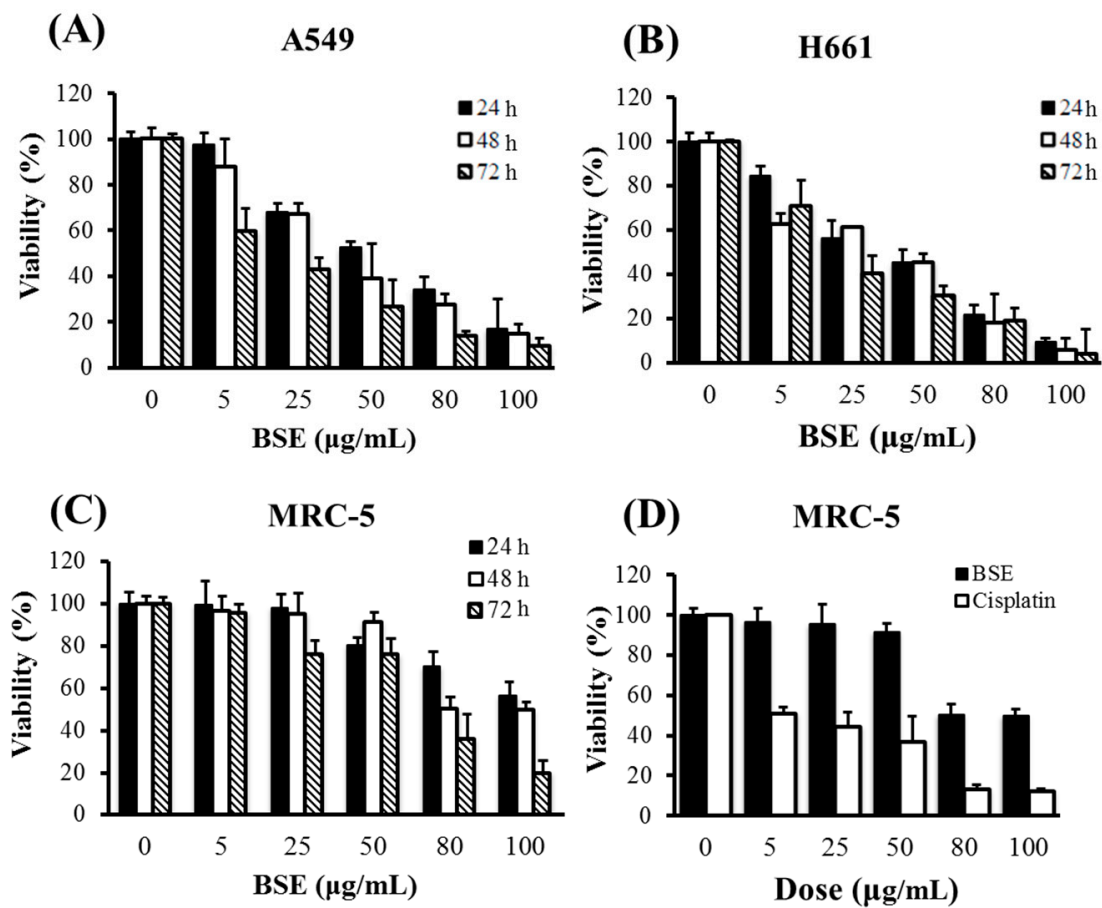

Figure 1. Effects of treatment concentration and duration of BSE on the proliferation of (A) lung cancer A549 cells, (B) H661 cells, (C) lung fibroblast MRC-5 normal cells, (D) the comparison of the effects of BSE and cisplatin on MRC- 5 cells under $48 \mathrm{~h}$ treatment. 
Table 1. Cytotoxicities (expressed by $\mathrm{IC}_{50}$ value) of BSE and cisplatin on different lung cells.

\begin{tabular}{ccccccc}
\hline \multirow{2}{*}{ Cell Line } & \multicolumn{3}{c}{ BSE $(\boldsymbol{\mu g} / \mathbf{m L})$} & \multicolumn{3}{c}{ Cisplatin $(\mu \mathrm{g} / \mathbf{m L})$} \\
\cline { 2 - 7 } & $\mathbf{2 4} \mathbf{h}$ & $\mathbf{4 8} \mathbf{h}$ & $\mathbf{7 2} \mathbf{~ h}$ & $\mathbf{2 4} \mathbf{~ h}$ & $\mathbf{4 8} \mathbf{h}$ & $\mathbf{7 2} \mathbf{~ h}$ \\
\hline A549 & 59.0 & 43.7 & 18.1 & 58.7 & 44.3 & 19.2 \\
H661 & 46.6 & 44.6 & 24.7 & 79.6 & 16.9 & 16.1 \\
MRC-5 & 120.8 & 89.7 & 61.1 & 34.1 & 10.7 & 7.8 \\
\hline
\end{tabular}

Mollah et al. [38,39] reported that the $\mathrm{IC}_{50}$ values of aqBSE on A549 and H460 cells for $24 \mathrm{~h}$ treatment were around $225 \mu \mathrm{g} / \mathrm{mL}$ and $75 \mu \mathrm{g} / \mathrm{mL}$, respectively. In comparison, the cytotoxicity of BSE is higher, i.e., the $\mathrm{IC}_{50}$ values for $24 \mathrm{~h}$ treatment were $59.0 \mu \mathrm{g} / \mathrm{mL}$ and $46.6 \mu \mathrm{g} / \mathrm{mL}$ on A549 and H661 cells, respectively. As mentioned previously, SFE is suitable for extracting non-polar or moderately polar ingredients; while the aqueous extraction would get the polar constituents of BS. Thus, the deviation of the cytotoxicities of these two extracts might be due to the difference of their compositions.

\subsection{Effects of BSE on Cell Cycle Regulation of Lung Cancer Cells}

The effects of BSE on cell cycle progression in A549 and H661 cells were investigated by the quantitation of the cell cycle distribution under treatment with different BSE concentrations for $48 \mathrm{~h}$ by flow cytometry (Figure 2). For these two cell lines, the number of cells in the $S$ phase and the $\mathrm{G}_{2} / \mathrm{M}$ phase rose significantly with increasing the BSE concentration from 0 to $88 \mu \mathrm{g} / \mathrm{mL}$ (Table 2). This experimental finding implies that BSE could arrest A549 and $\mathrm{H} 661$ cells at $\mathrm{S}$ and $\mathrm{G}_{2} / \mathrm{M}$ phase. In contrast, the aqBSE arrests A549, S180 and H460 lung cancer cells at the sub-G1 phase [38,39].
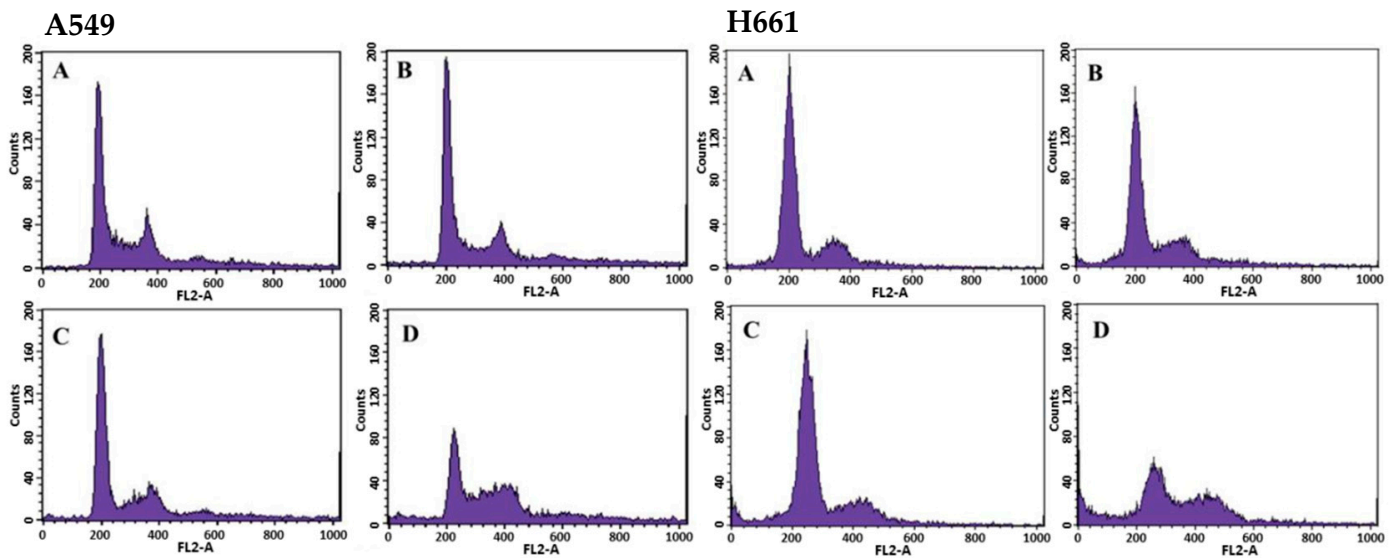

Figure 2. Cell cycle analysis of A549 and H661 cells treated with different concentrations of BSE by flow cytometry. The cells $\left(1 \times 10^{6}\right.$ cells) were incubated with: (A) $0 \mu \mathrm{g} / \mathrm{mL}$ (Control), (B) $22 \mu \mathrm{g} / \mathrm{mL}$, (C) $44 \mu \mathrm{g} / \mathrm{mL}$, (D) $88 \mu \mathrm{g} / \mathrm{mL}$ of BSE for $48 \mathrm{~h}$. The percentage of each phase was analyzed by WinMDI 2.5 software.

Table 2. Distribution of lung cancer cells arrested at different phases after the treatment of different BSE concentrations for $48 \mathrm{~h}$ *.

\begin{tabular}{|c|c|c|c|c|c|c|c|c|}
\hline \multirow{2}{*}{$\begin{array}{l}\text { BSE Conc. } \\
(\mu \mathrm{g} / \mathrm{mL})\end{array}$} & \multicolumn{4}{|c|}{ A549 Cells } & \multicolumn{4}{|c|}{ H661 Cells } \\
\hline & $\mathrm{SubG}_{1}(\%)$ & $\mathrm{G}_{0} / \mathrm{G}_{1}(\%) *$ & $\mathrm{~S}(\%) *$ & $\mathrm{G}_{2} / \mathrm{M}(\%) *$ & $\mathrm{SubG}_{1}(\%)$ & $\mathrm{G}_{0} / \mathrm{G}_{1}(\%) *$ & $\mathrm{~S}(\%) *$ & $\mathrm{G}_{2} / \mathrm{M}(\%)$ * \\
\hline 0 & $0.37 \pm 0.08$ & $65.89 \pm 1.33$ & $10.61 \pm 0.55$ & $23.50 \pm 1.83$ & $2.96 \pm 0.40$ & $76.75 \pm 0.51$ & $4.72 \pm 0.29$ & $18.53 \pm 0.23$ \\
\hline 22 & $0.56 \pm 0.07$ & $65.87 \pm 3.50$ & $9.99 \pm 0.58$ & $24.15 \pm 3.30$ & $4.48 \pm 0.50$ & $77.64 \pm 0.36$ & $4.80 \pm 0.33$ & $17.56 \pm 0.42$ \\
\hline 44 & $1.54 \pm 0.10$ & $65.06 \pm 1.64$ & $11.78 \pm 0.49$ & $23.16 \pm 2.12$ & $5.97 \pm 0.47$ & $72.28 \pm 0.99$ & $7.33 \pm 0.24$ & $20.39 \pm 1.04$ \\
\hline 88 & $4.59 \pm 0.16$ & $42.25 \pm 2.10$ & $19.86 \pm 3.83$ & $37.89 \pm 5.93$ & $14.17 \pm 0.31$ & $52.85 \pm 2.33$ & $11.43 \pm 1.49$ & $35.72 \pm 2.88$ \\
\hline
\end{tabular}

\footnotetext{
* Percentages of the cell distribution of $\mathrm{G}_{0} / \mathrm{G}_{1}, \mathrm{~S}$ and $\mathrm{G}_{2} / \mathrm{M}$ phases were calculated without the ratio of Sub-G1. The data are expressed as Mean $\pm \mathrm{SD}$ in triplicate analysis.
} 


\subsection{BSE Treatment Caused A549 and H661 Necrosis but not Apoptosis}

The Annexin V-FITC/PI detection kit was used to stain the cells and to examine the influence of BSE on cancer cell death by flow cytometry. Binding of Annexin V to phosphatidylserine (PS) of cells and the staining of PI on nucleus are the unique properties of apoptotic cell and necrotic cell, respectively. The analytical results are expressed in four quadrants (Figure 3). In general, the dots in the lower left (LL, annexin $\mathrm{V}^{-} / \mathrm{PI}^{-}$) quadrant are viable cells; those in the upper left (UL, annexin $\left.\mathrm{V}^{-} / \mathrm{PI}^{+}\right)$quadrant are cells in necrosis; while those in the lower right (LR, annexin $\left.\mathrm{V}^{+} / \mathrm{PI}^{-}\right)$quadrant are cells undergoing early apoptosis; upper right (UR, annexin $\mathrm{V}^{+} / \mathrm{PI}^{+}$) quadrant are cells in late apoptosis. Figure 3 shows the cell death pattern of H661 cancer cells under the BSE treatment. The dots dispersed and shifted to the UL side, i.e., in necrosis, in a dose- and time-dependent manner.

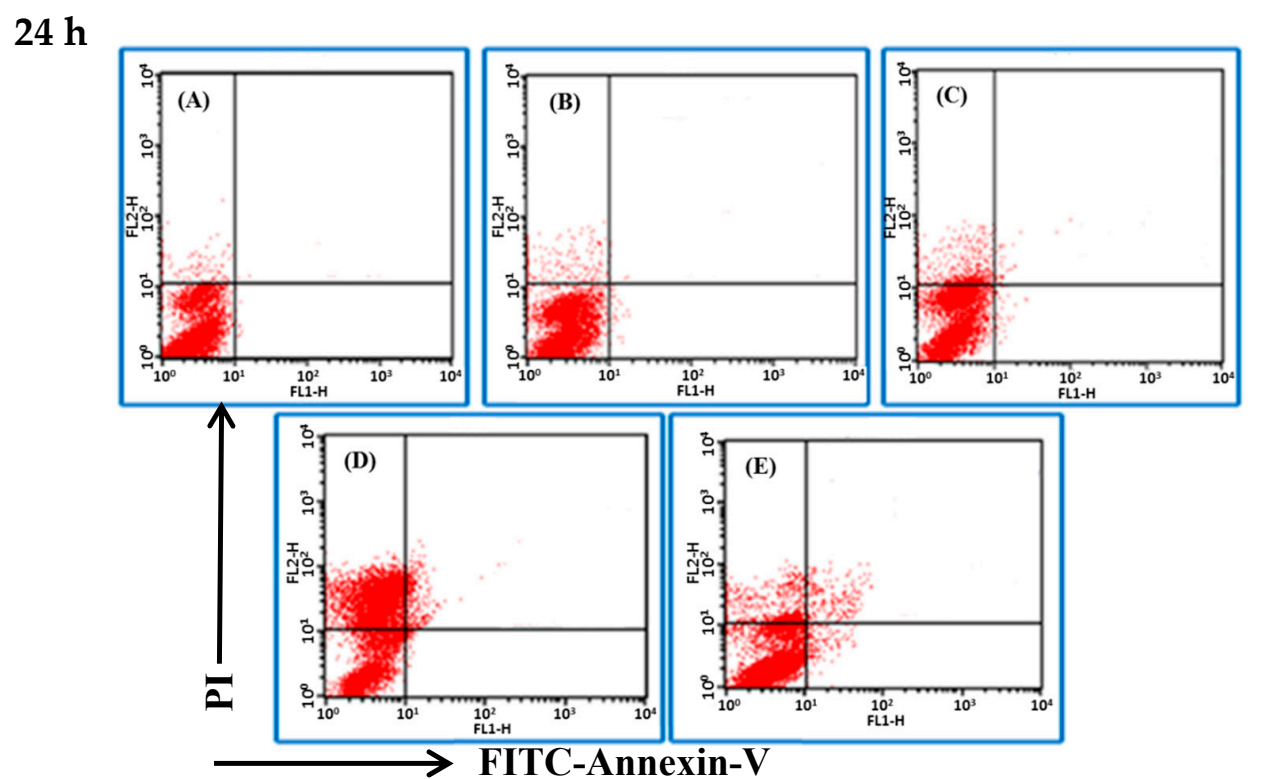

$48 \mathrm{~h}$

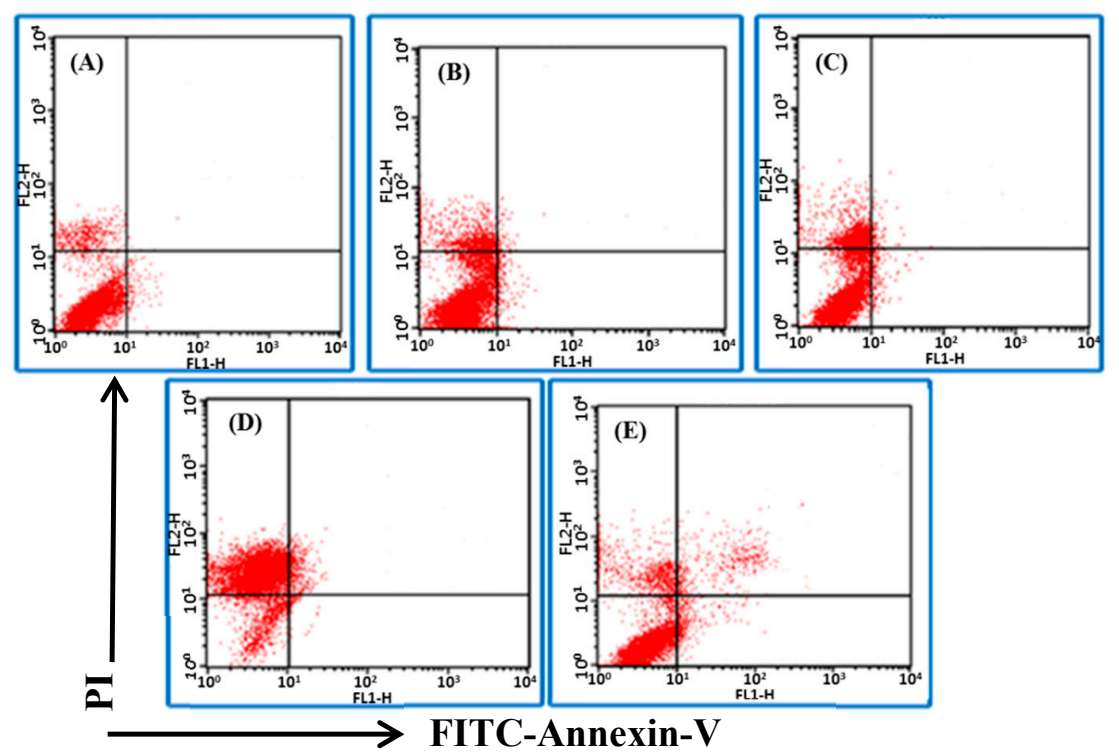

Figure 3. Effects of BSE on H661 cell death pattern under the treatment of different durations (24 and $48 \mathrm{~h}$ ) and different concentrations of BSE: (A) $0 \mu \mathrm{g} / \mathrm{mL}$ (Control), (B) $22 \mu \mathrm{g} / \mathrm{mL}$, (C) $44 \mu \mathrm{g} / \mathrm{mL}$, (D) $88 \mu \mathrm{g} / \mathrm{mL}$, (E) Cisplatin in $100 \mu \mathrm{g} / \mathrm{mL}$. Lower left (LL) quadrant: viable cells; upper left (UL) quadrant: necrotic cells; lower right (LR) quadrant: early apoptotic cells; upper right (UR) quadrant: late apoptotic cells. 
The flow data show that BSE had no significant effect on the induction of apoptosis on H661 cells. In contrast, cisplatin induced some cells to die in necrosis, while some died by apoptosis (Figure 3E). The same analysis was also performed on A549 cells and a similar necrotic effect was observed (Figure 4). These data demonstrate that the major type of cell death of H661 and A549 stimulated by BSE is necrosis but not apoptosis.
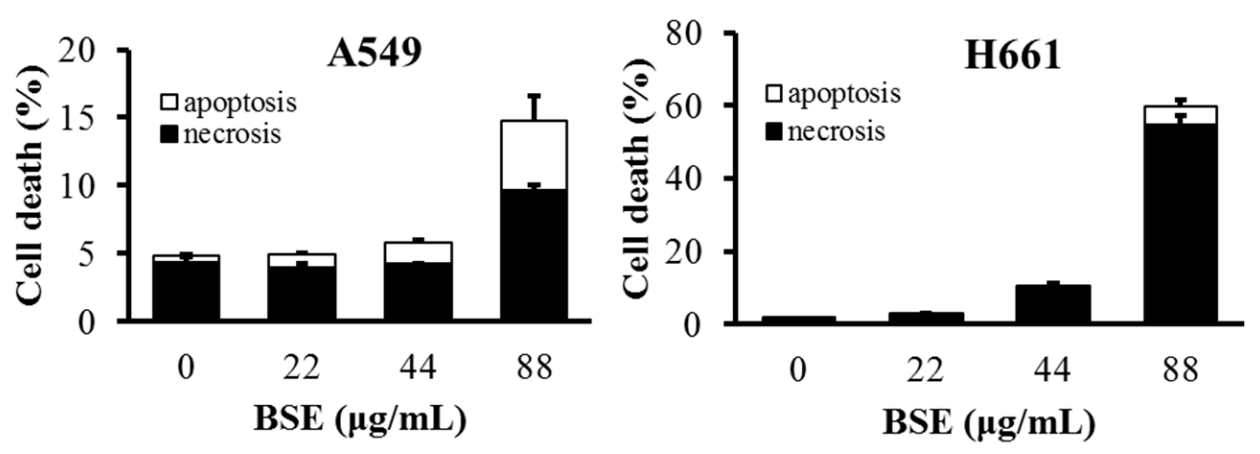

Figure 4. The ratio of apoptosis and necrosis induced by different concentrations of BSE on A549 and H661 cells for $24 \mathrm{~h}$ treatment.

\subsection{Effect of BSE on Protein Expression Related to Necroptosis}

As mentioned earlier, necroptosis is a form of regulated cell death. The expression of RIP-1 and/or RIP-3, and specifically inhibited by Nec-1 are the crucial characteristics of necroptosis $[4,5,41,42]$. To characterize the type of necrosis that BSE triggered, we first tested whether Nec-1 could inhibit BSE-stimulated necrosis in lung cancer cells. The H661 cells were pretreated by $20 \mu \mathrm{M} \mathrm{Nec}-1$ for $30 \mathrm{~min}$, and then treated with BSE. Data in Figure 5A show that Nec-1 nearly completely inhibited BSE-induced cell death in H661 cells. This finding suggests that the cell death induced by BSE in H661 cells was necroptosis. In addition, Figure 5B shows that the RIP-1 was highly expressed on BSE-treated H661 cells, while the level of RIP-3 was only slightly enhanced under BSE treatment. These results indicate that the type of necrosis triggered by BSE was necroptosis through RIP-1 induction.

Necroptosis could be induced by stimulating death receptors with agonists such as TNF- $\alpha$, FasL, and TRAIL $[5,41]$. TNF- $\alpha$ stimulation can transduce necroptosis signal in the absence of caspase- 8 activity [43]. Figure 5C shows that TNF- $\alpha$ was highly expressed when H661 cells were treated with 10 to $40 \mu \mathrm{g} / \mathrm{mL}$ of BSE. Moreover, the protein level of procaspase- 8 had no significant change under BSE treatment. Accordingly, these results indicate that the necroptosis might be stimulated by TNF- $\alpha$ in the absence of caspase- 8 activity.

In contrast, Mollah et al. [38,39] demonstrated that aqBSE triggers lung cancer cell death through the apoptosis process by the evidences of DNA fragmentation, annexin V staining, and the results of immunoblot analysis, i.e., treatment with aqBSE would increase the expressions of p53 and Bax and down-regulate Bcl-2 protein in cancer cells.

\subsection{BSE Inhibits the Migration and Invasion of A549 and H661 Cells}

To study the anti-metastatic effect of BSE on lung cancer cells, the inhibitory effects of BSE on migration and invasion of cancer cells were investigated by using the wound healing assay and Boyden chamber assay. At first, A549 and H661 cells were incubated in the absence or presence of BSE for the wound healing assay. Figure 6 shows that incubation with BSE significant decreased the migration of A549 and H661 cells into the wounded area in a time- and dose-dependent manner. Comparing these results with the control $(0 \mu \mathrm{g} / \mathrm{mL})$, the treatment at 10 and $20 \mu \mathrm{g} / \mathrm{mL}$ of BSE reduced the cancer cell migration by around $64 \%$ and $89 \%$ on A549 cells and by around $47 \%$ and $72 \%$ on H661 cells at $24 \mathrm{~h}$, respectively. Furthermore, the results of Boyden chamber assay using a transwell chamber are demonstrated in Figure 7. The stained migratory cells treated by 10 and $20 \mu \mathrm{g} / \mathrm{mL}$ BSE were 
significantly reduced by around $46 \%$ and $90 \%$ comparing with the control on A549 cells and around $74 \%$ and $81 \%$ on $\mathrm{H} 661$ cells.

(A)

\section{H661 for $48 \mathrm{~h}$}

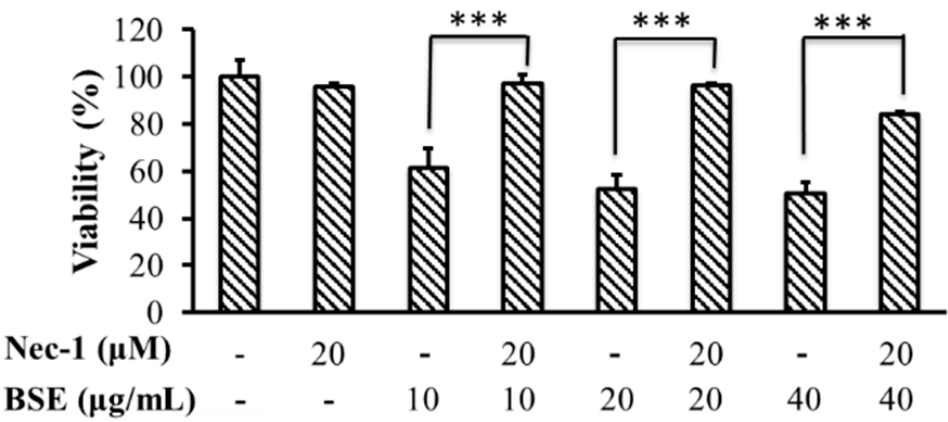

(B)
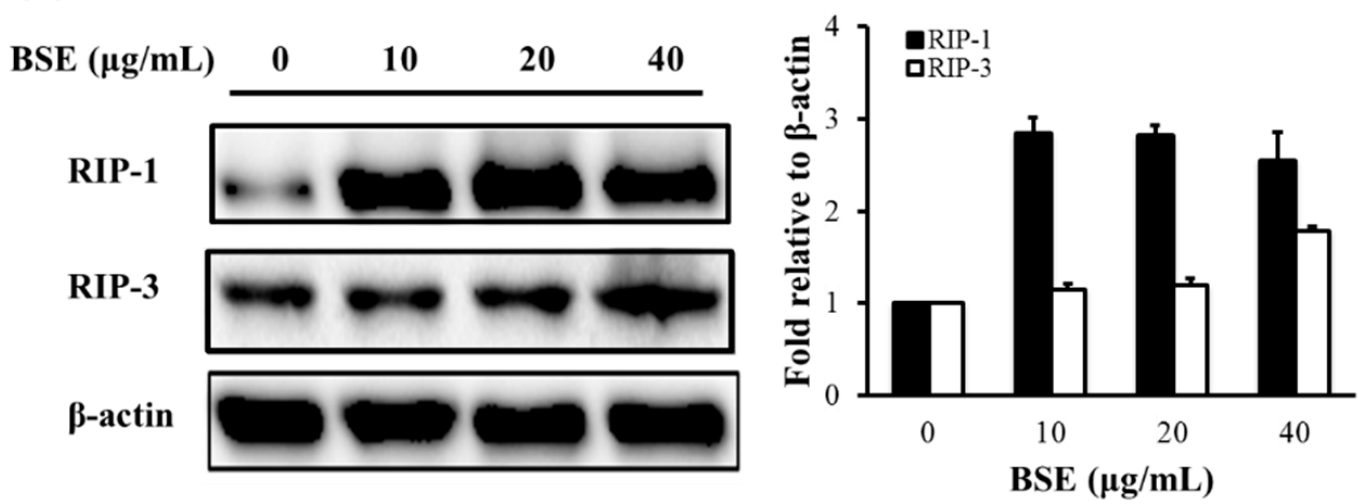

(C)
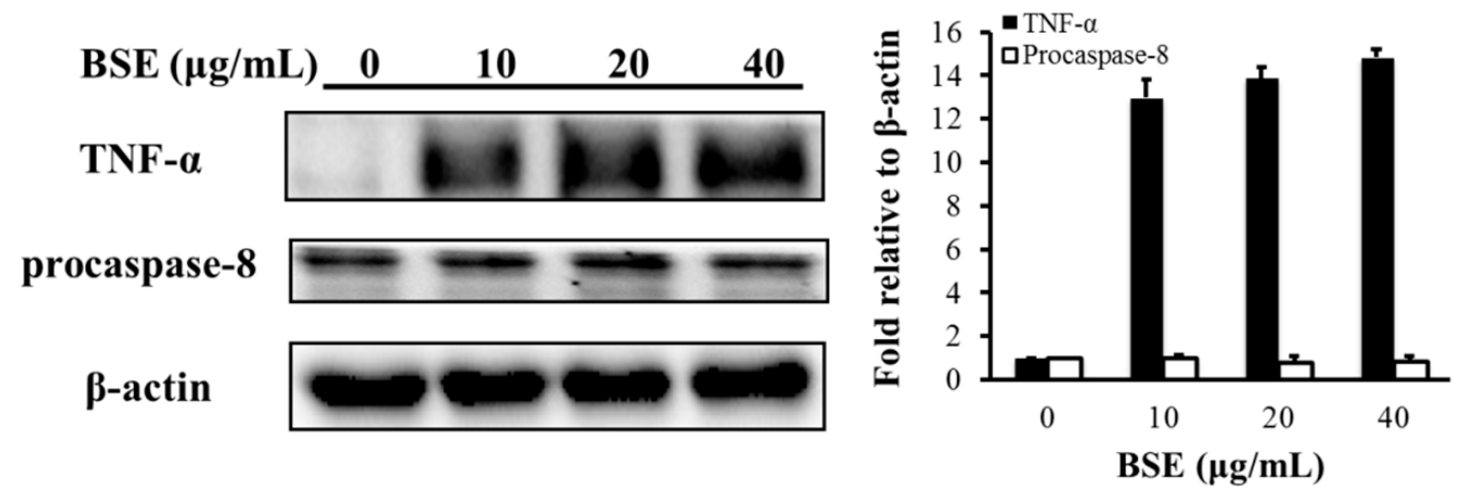

Figure 5. BSE induces cell death via necroptotic pathway in the H661 cells. (A) Cytotoxic effect of BSE is reverted by Nec-1. H661 cells were pretreated with or without $20 \mu \mathrm{M}$ nec-1 for $30 \mathrm{~min}$ and then treated with different doses of BSE $(10,20$ and $40 \mu \mathrm{g} / \mathrm{mL})$ or DMSO $(0 \mu \mathrm{g} / \mathrm{mL})$ for $48 \mathrm{~h}$. The viability of these cells was measured by MTT assay. A significant difference between the denoted two experiments was indicated as *** $p<0.001$. (B) BSE induces RIP-1 expression in H661 cells; (C) BSE induces TNF- $\alpha$ expression in the absence of caspase- 8 activity in H661 cells. Cell extracts from BSE administration were harvested at $24 \mathrm{~h}$ and subjected to western blot analysis. Densitometric analyses of protein were normalized to the loading control $\beta$-actin. 

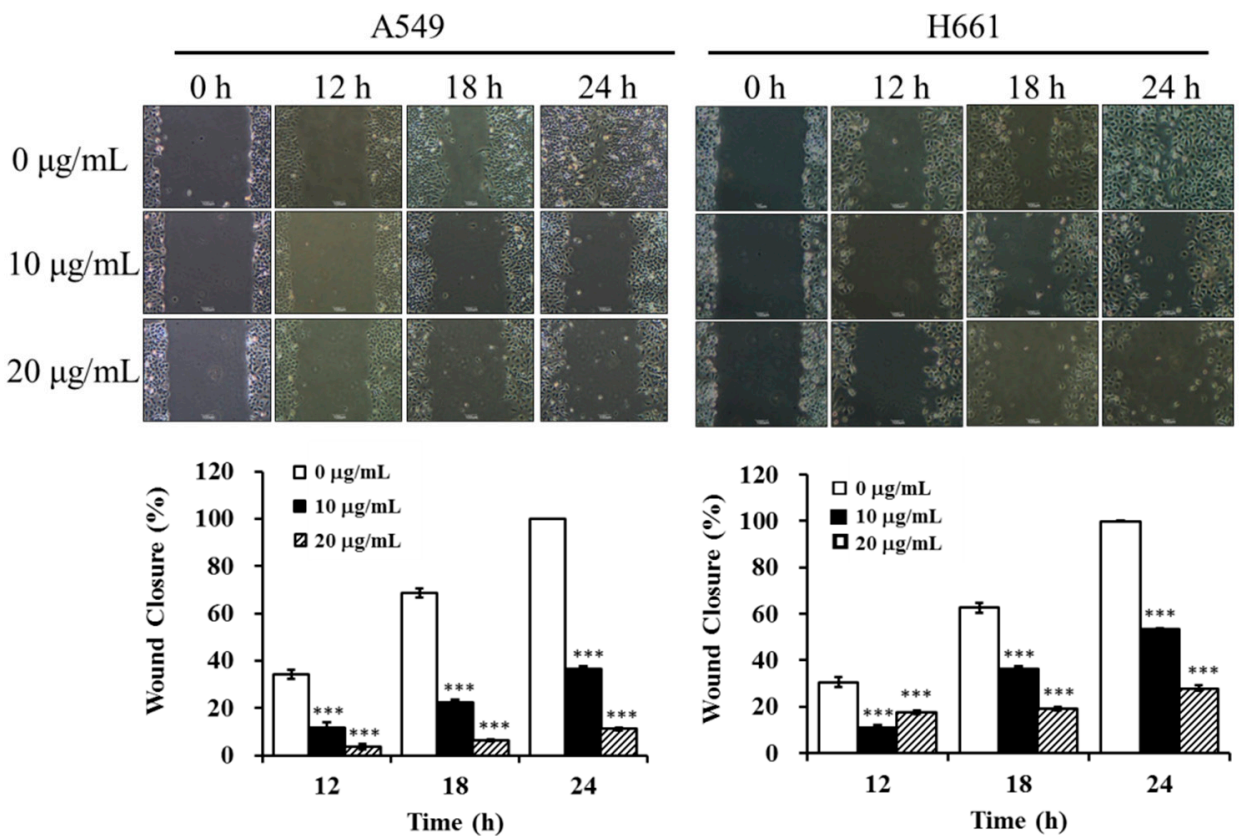

Figure 6. Effect of BSE on A549 and H661 cell migration by wound healing assay. A549 and H661 were seeded into culture dishes and grown to $90 \%$ confluence in $6 \mathrm{~cm}$ dishes. The cells were scratched with a sterile tip, BSE $(0,10$ and $20 \mu \mathrm{g} / \mathrm{mL})$ were added and the wounded area were photographed at $0,12,18$ and $24 \mathrm{~h}$. The inhibitory effect on cell migration is expressed as the level of wound closure. A significant difference from the vehicle was indicated as ${ }^{* * *} p<0.001$ (Student's $t$-test).

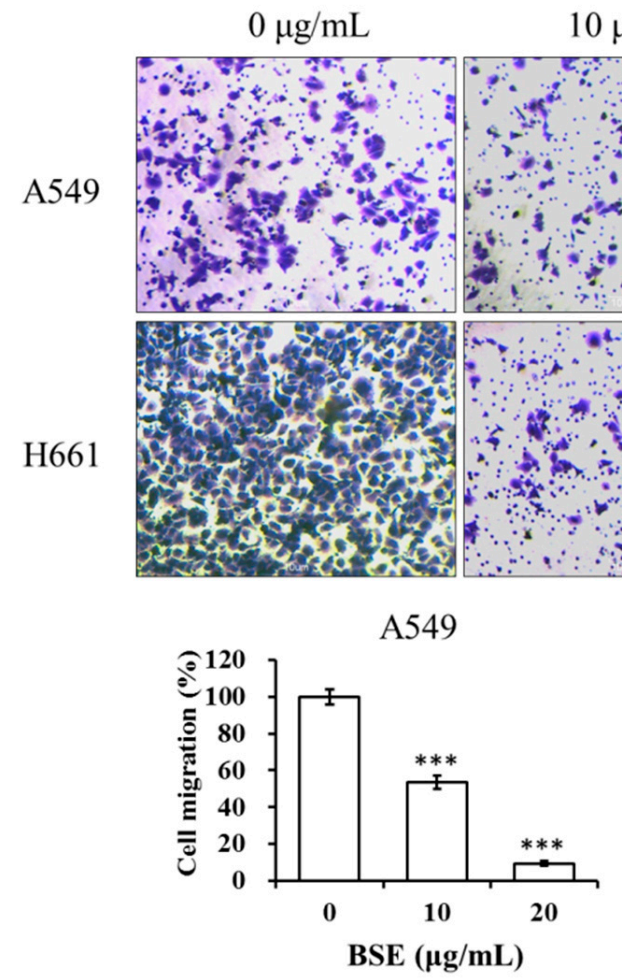

$0 \mu \mathrm{g} / \mathrm{mL}$

$20 \mu \mathrm{g} / \mathrm{mL}$
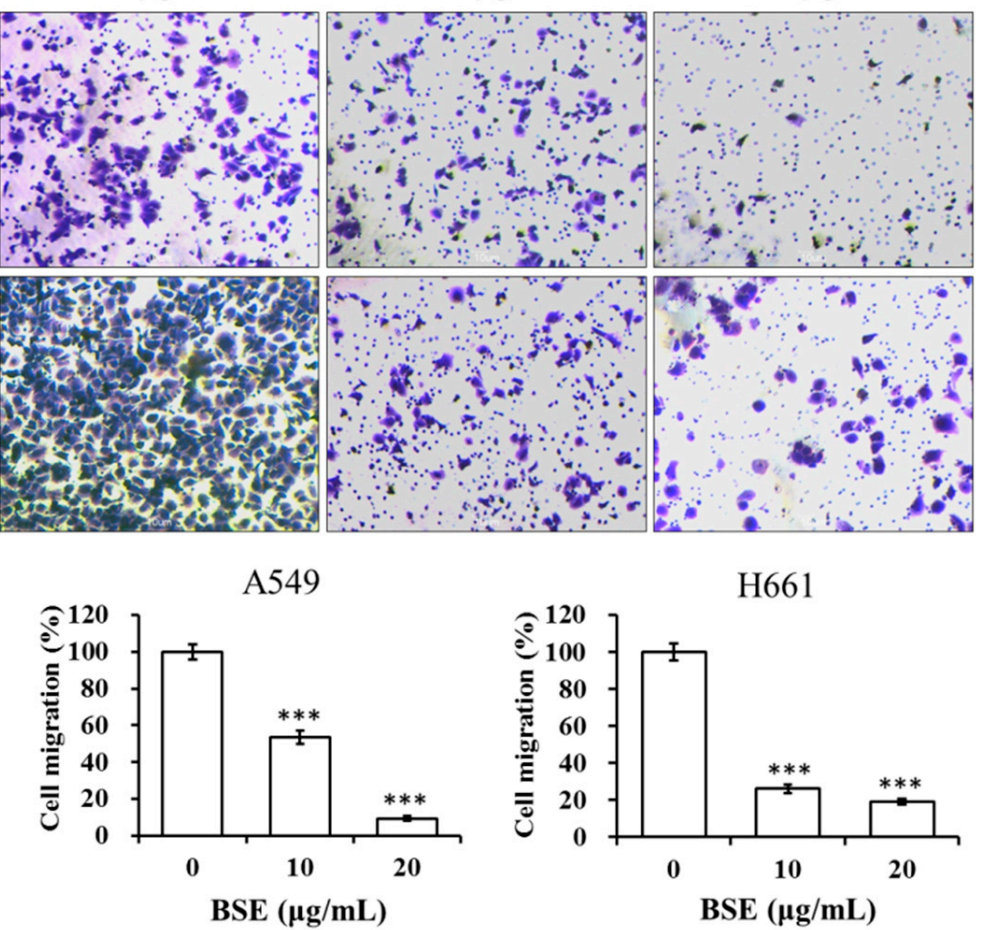

Figure 7. Effect of BSE on A549 and H661 cell migration by transwell assay. An aliquot of $2 \times 10^{5}$ cells of A549 and H661, respectively, were seeded onto the upper chamber in serum-free medium with BSE $(0,10$ and $20 \mu \mathrm{g} / \mathrm{mL})$ for $24 \mathrm{~h}$. The cells migrated through polycarbonate membrane were stained with crystal violet and photographed. The crystal violet-stained cells were calculated. A significant difference from the vehicle was indicated as ${ }^{* * *} p<0.001$ (Student's $t$-test). 
The inhibitory effects of BSE on the invasion of lung cancer cells were examined by a cell invasion assay with the Boyden chamber coated with collagen. The number of A549 and H661 cells that invaded through the Matrigel was significantly inhibited by BSE treatment (Figure 8). Quantification of cells in the lower chamber indicates that BSE treatment significantly inhibited A549 and H661 cell invasion in a concentration-dependent manner. The cell invasion rate is expressed as a percentage to the control $(0 \mu \mathrm{g} / \mathrm{mL})$. When treating with $10 \mu \mathrm{g} / \mathrm{mL}$ BSE, the percentage of invasive cells decreased to $50 \%$ and $31 \%$ on A549 and H661 cells, respectively. While at the concentration of $20 \mu \mathrm{g} / \mathrm{mL} \mathrm{BSE}$, the cell invasions were almost totally inhibited, i.e., the invasive activity were $9 \%$ and 7\% on A549 and H661 cells, respectively. In summary, these results suggested that BSE displayed strong inhibitory effects on the migration and invasion of A549 and H661 cancer cells.
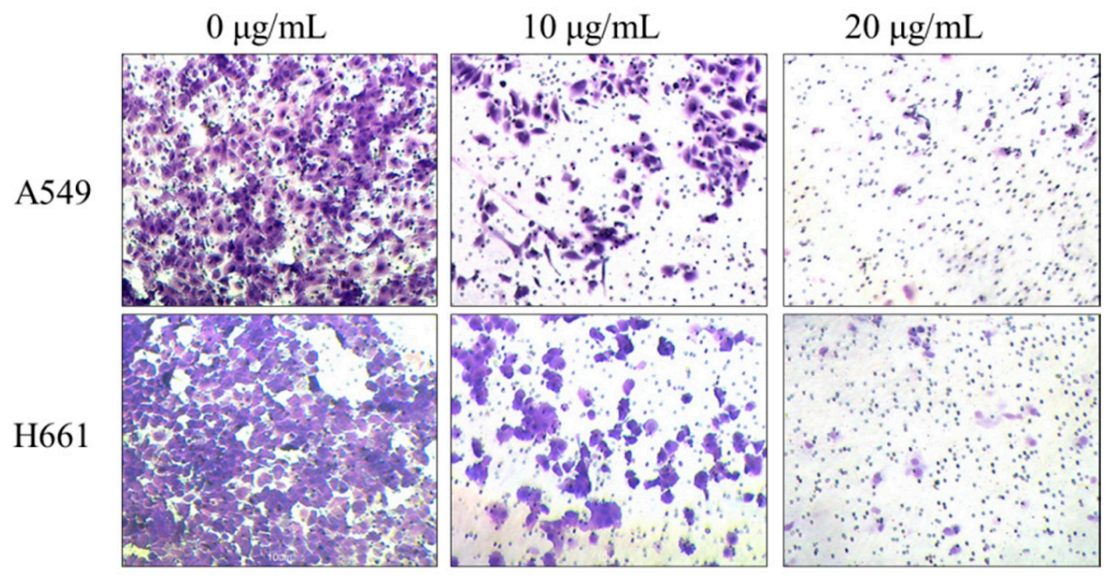

A549
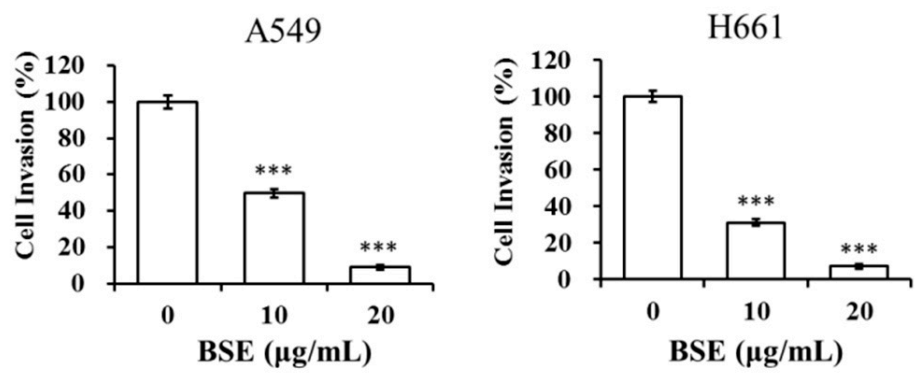

Figure 8. Effect of BSE on $\mathrm{A} 549$ and $\mathrm{H} 661$ cell invasion. A BD BioCoat ${ }^{\mathrm{TM}}$ Matrigel $^{\mathrm{TM}}$ invasion chamber was used for invasion assay. An aliquot of $2 \times 10^{5}$ cells of A549 and H661, respectively, were seeded onto the upper chamber in serum-free medium with BSE $(0,10$ and $20 \mu \mathrm{g} / \mathrm{mL})$ for $24 \mathrm{~h}$. The cells invaded through Matrigel were stained with crystal violet and photographed. The crystal violet-stained cells were calculated. A significant difference from the vehicle was indicated ${ }^{* * *} p<0.001$ (Student's $t$-test).

\subsection{Cytotoxicity of Main Ingredients of BSE on Lung Cancer Cells}

The gas chromatography-mass spectrometry (GC-MS) analytical results show that BSE contains at least 25 ingredients (Figure 9), of which 10 compounds were identified using the NIST spectral database of the mass spectrometry. The main constituents of BSE were identified as $\alpha$-guaiene (relative content $\mathrm{RC}=34.0 \%$; retention time $\mathrm{RT}=25.21 \mathrm{~min}),(-)$-guaiol $(\mathrm{RC}=28.7 \%$; $\mathrm{RT}=23.69 \mathrm{~min}),(-)$-nortrachelogenin $(\mathrm{RC}=8.3 \% ; \mathrm{RT}=43.04 \mathrm{~min}), \beta$-eudesmol $(\mathrm{RC}=6.4 \% ; \mathrm{RT}=28.20 \mathrm{~min})$ and $\beta$-caryophyllene $(\mathrm{RC}=1.4 \%$; $\mathrm{RT}=12.55 \mathrm{~min})$. The identities of $\alpha$-guaiene, $(-)$-guaiol, $\beta$-eudesmol and $\beta$-caryophyllene were further confirmed by comparing their mass spectral data with the analytical results from the commercially available products, while (-)-nortrachelogenin was commercially unavailable. 


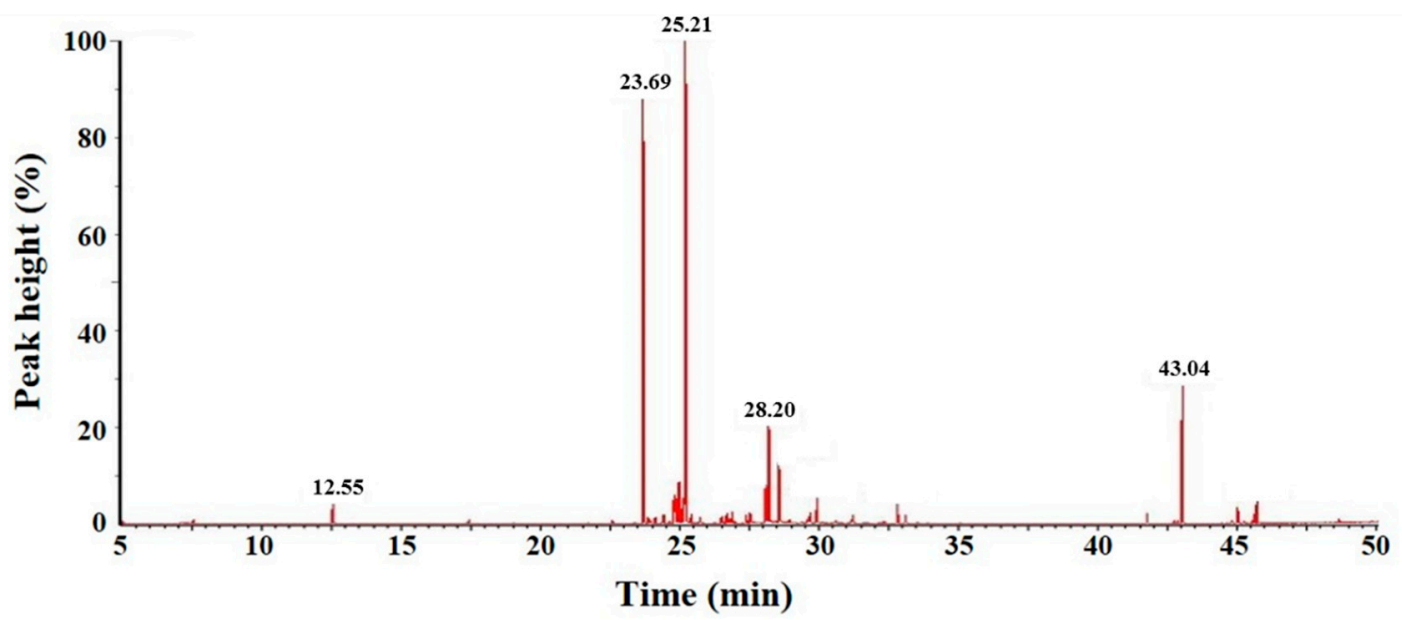

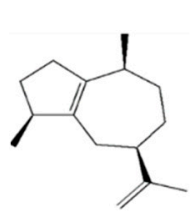

o-Guaiene

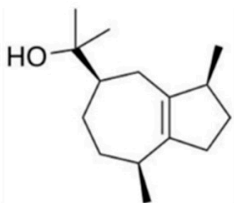

(-)-Guaiol<smiles>C=C1CCCC2(C)C(C)CCC1C2(C)O</smiles>

B-Eudesmol

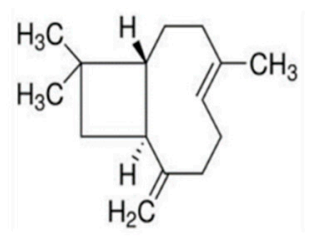

$\beta$-Caryophyllene

Figure 9. Gas chromatography-mass spectrometry profile of BSE sample and the four ingredients identified from this analysis. These four compounds were confirmed by comparing with their mass spectral data with the NIST mass spectral library and commercially available products.

The cytotoxicity assessments of these four compounds on two lung cancer cell lines for $48 \mathrm{~h}$ treatment are shown in Figure 10. The cytotoxicity (expressed by $\mathrm{IC}_{50}$ value) of $\alpha$-guaiene, (-)-guaiol and $\beta$-caryophyllene to A549 cells were $142.6 \pm 5.1 \mu \mathrm{g} / \mathrm{mL}(0.698 \pm 0.025 \mathrm{mM}), 110.8 \pm 4.0 \mu \mathrm{g} / \mathrm{mL}$ $(0.618 \pm 0.022 \mathrm{mM})$ and $150.2 \pm 3.7 \mu \mathrm{g} / \mathrm{mL}(0.685 \pm 0.017 \mathrm{mM})$, respectively. To H661 cells, the $\mathrm{IC}_{50}$ values of these three ingredients were $69.9 \pm 1.3 \mu \mathrm{g} / \mathrm{mL}(0.342 \pm 0.006 \mathrm{mM}), 111.9 \pm 3.1 \mu \mathrm{g} / \mathrm{mL}$ $(0.624 \pm 0.017 \mathrm{mM})$ and $106.2 \pm 3.3 \mu \mathrm{g} / \mathrm{mL}(0.520 \pm 0.016 \mathrm{mM})$, respectively. The cytotoxicities of $\beta$-eudesmol to these two cancer cell lines were insignificant. Therefore, $\alpha$-guaiene, $(-)$-guaiol and $\beta$-caryophyllene should be responsible for the main cytotoxicity of BSE against A549 and H661 cells.

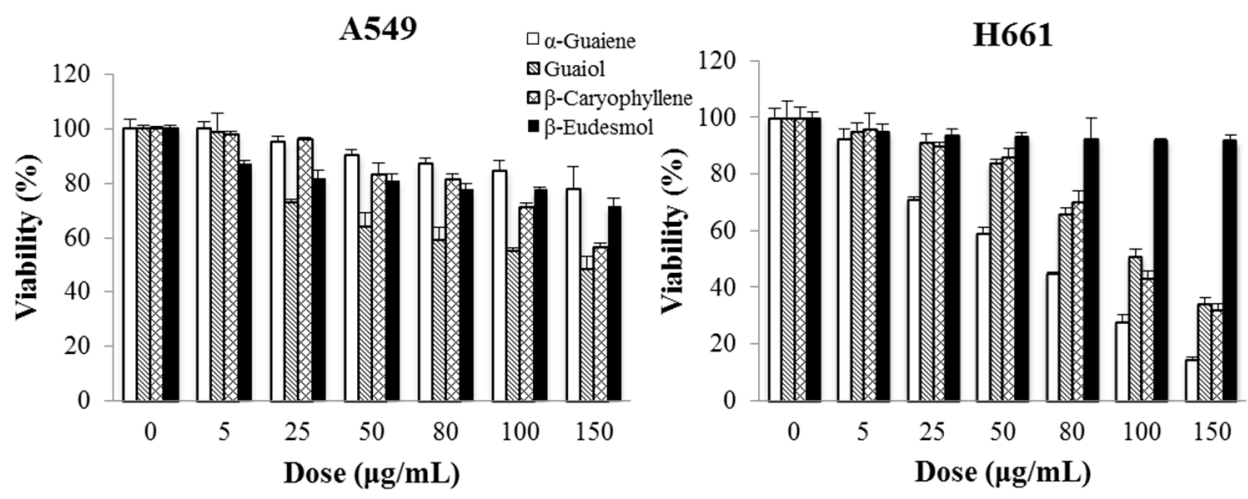

Figure 10. Cytotoxicities of $\alpha$-guaiene, (-)-guaiol, $\beta$-caryophyllene and $\beta$-eudesmol on A549 and H661 cells for $48 \mathrm{~h}$ treatment.

$\alpha$-Guaiene is a sesquiterpene and exists in the extracts of numerous plants [44-46]. However, there has been little literature reported on its anti-cancer activity. (-)-Guaiol is a sesquiterpene alcohol and is a key component of many medicinal plants $[47,48]$. It has been demonstrated that $(-)$-guaiol possesses significant cytotoxicity on NSCLC cells and regulates autophagic cell death $[49,50]$. $\beta$-Caryophyllene, 
an important component in the extracts of various species of medicinal plants, has been reported to have anti-proliferative effects on various cancer cells, including pancreatic cancer, colon cancer [51], hepatoma [52], endometrial cancer [53], and skin epidermoid cancer [54].

Rodilla et al. [35] reported that the major components of their BS essential oil were bulnesol $(\mathrm{RC}=34.7 \%)$ and guaiol $(\mathrm{RC}=20.4 \%) . \alpha$-Guaiene $(\mathrm{RC}=0.2 \%), \beta$-caryophyllene $(\mathrm{RC}=0.1 \%)$ and $\beta$-eudesmol $(\mathrm{RC}=1.3 \%)$ were also presented but in a small amount. The difference in the composition between this essential oil extract and BSE should be mainly due to the difference in extraction methods, in which the former and the latter were prepared by steam distillation and SFE, respectively.

As for the aqBSE, the analytical results from high performance liquid chromatography (HPLC) show that the main active ingredients are various types of catechins, such as (-)-epigallocatechin, (-)-epicatechin, (-)-epicatechin gallate, and (+)-catechin gallate; and these catechins have their own anti-cancer effects [39].

\section{Materials and Methods}

\subsection{Reagents}

Dulbecco's modified Eagle's medium (DMEM), fetal bovine serum, RPMI-1640 medium, L-glutamine, penicillin and streptomycin were from Gibco (Grand Island, NY, USA). 3-(4,5-Dimethylthiazol-2-yl)-2,5-diphenyl tetrazolium bromide (MTT) and necrostatin-1 reagent were purchased from Sigma-Aldrich (St. Louis, MO, USA). Antibodies to RIP-1 and TNF- $\alpha$ were purchased from Cell Signaling Technology (Danvers, MA, USA). Primary antibody to RIP-3 and the horseradish peroxidase-conjugated anti-rabbit and anti-mouse IgG secondary antibodies were obtained from Millipore Co. (Temecula, CA, USA). Antibodies to procaspase-8 and $\beta$-actin were separately purchased from BD Bioscience (San Jose, CA, USA) and Santa Cruz Biotechnology (Santa Cruz, CA, USA). All chemicals used in this study were of reagent or higher grade.

\subsection{Preparation of $B S E$}

The wood waste material of BS (imported from South America) was purchased from a local wood furniture company (Chiayi, Taiwan). The supercritical- $\mathrm{CO}_{2}$ fluid extract (BSE) was prepared by processing $2 \mathrm{~kg}$ of the crushed powder in the supercritical fluid extractor $(5 \mathrm{~L} / 1000 \mathrm{bar} R \& \mathrm{D}$ unit, Natex, Ternitz, Austria). The dynamic extractions were performed as: 0-150 bar for 20 min; 150-250 bar for $20 \mathrm{~min} ; 250-300$ bar for $10 \mathrm{~min} ; 300-350$ bar for $10 \mathrm{~min}$; and stay at $350 \mathrm{bar}, 40^{\circ} \mathrm{C}$ for $2 \mathrm{~h}$. The extracted sample was dried in a freeze-dryer. The resulting extract was $208 \mathrm{~g}$. The extraction yield was $10.4 \%$. The BSE was stored at $-20^{\circ} \mathrm{C}$ and dissolved in dimethyl sulfoxide (DMSO) before use. The final DMSO concentration in the medium was less than $0.1 \%$.

\subsection{Cell Culture}

Human lung carcinoma cell line A-549 (BCRC 60074), H661 (BCRC 60125) and human lung normal fibrobast MRC-5 (BCRC 60023) were purchased from Bioresource Collection and Research Center (BCRC, Hsinchu, Taiwan). A-549 and MRC-5 cells were grown in DMEM with 10\% fetal bovine serum, $1 \%$ penicillin/streptomycin, and supplemented with $2 \mathrm{mM}$ L-glutamine. H661 cells were grown in RPMI-1640 medium supplemented with $10 \%$ fetal bovine serum, $1 \%$ penicillin/streptomycin, and $2 \mathrm{mM}$ L-glutamine. Cells were subcultured every two days and cultivated in a humidified incubator at $37^{\circ} \mathrm{C}$ with $5 \% \mathrm{CO}_{2}$ and $95 \%$ air.

\subsection{Cytotoxicity Assay}

Cancer cells were cultured in 96-well plates at $1 \times 10^{4}$ cells for $24 \mathrm{~h}$ before treatment. The indicated concentration of BSE was then added. After cultivation for the given period, the culture medium was replaced by $100 \mu \mathrm{L}$ of the culture medium containing $0.5 \mathrm{mg} / \mathrm{mL}$ MTT assay kit (Sigma-Aldrich Chemicals), and the cells were further incubated for $2 \mathrm{~h}$. The medium solution was removed 
and an aliquot of $100 \mu \mathrm{L}$ DMSO was added. The plate was shaken until the crystals dissolved. The cytotoxicity against the tested cells was measured at $570 \mathrm{~nm}$ using an ELISA reader (Model 550, Bio-Rad Laboratories, Hercules, CA, USA).

\subsection{Flow Cytometric Analysis on Cell Cycle}

Lung cancer cells $\left(1 \times 10^{6}\right.$ cells) were incubated in a $10 \mathrm{~cm}$ dish for $24 \mathrm{~h}$. Treated with various concentrations of BSE for $48 \mathrm{~h}$. The treated cells were harvested, washed with phosphate-buffer saline (PBS) and treated with $100 \mu \mathrm{L}$ trypsin-EDTA solution to detach the cells. The suspension solution was collected and centrifuged at $200 \times g$ for $10 \mathrm{~min}$. The cell pellet was washed with PBS, and then fixed in $70 \%$ ethanol at $4{ }^{\circ} \mathrm{C}$ overnight. After washing twice with cold PBS, cells were suspended in PBS that contained $40 \mu \mathrm{g} / \mathrm{mL}$ propidium iodide (PI) and $0.1 \mathrm{mg} / \mathrm{mL}$ RNase A (Gentra Systems Inc., Minneapolis, MN, USA), and was kept at $4{ }^{\circ} \mathrm{C}$ for $12 \mathrm{~h}$. The stained cells were then analyzed with BD FACSCalibur ${ }^{\mathrm{TM}}$ flow cytometer (BD Bioscience, Franklin Lakes, NJ, USA). The percentages of cell cycles were calculated by WinMDI 2.9 software (TSRI, La Jolla, CA, USA).

\subsection{Measurement of Apoptotic Ratio of A549 Cells}

The necrotic and apoptotic cells were analyzed with Annexin-V-FITC apoptosis detection kit (AVK050, Strong Biotech Co., Taipei, Taiwan). Lung cancer cells $\left(1 \times 10^{6}\right.$ cells) were incubated in $10 \mathrm{~cm}$ dish for $24 \mathrm{~h}$. After treating with different concentrations of BSE for 24 and $48 \mathrm{~h}$, the treated cells were harvested, washed with PBS, and then treated with trypsin-EDTA solution to detach the cells. The suspended cells were centrifuged at $200 \times g$ for $10 \mathrm{~min}$. After washing twice with cold PBS, cells were collected by centrifugation at $200 \times g$ for $5 \mathrm{~min}$, and stained with FITC-conjugated annexin

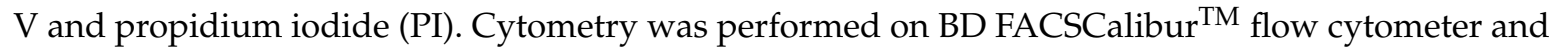
analyzed with WinMDI 2.9 software.

\subsection{Cell Migration by Wound Healing Assay}

An aliquot of $1 \times 10^{6}$ cells were seeded into $6 \mathrm{~cm}$ dish and cultured for $24 \mathrm{~h}$. Cells wound was artificially injured by using a sterile pipette tip. The cells were washed twice with PBS buffer to remove detached cells and cell debris. After which the culture medium containing certain dose of BSE was added. Cell migration into the wounded area was photographed at different time points using an inverted phase-contrast microscope (Nikon Eclipse TS100, Chiyoda-ku, Tokyo, Japan) at a magnification of $4 \times$. All wound healing assays were conducted in triplicate. The closure rate was calculated using the following formula:

Wound closure rate $(\%)=($ Original width - Width after migration $) /$ Original width $\times 100 \%$

\subsection{Cell Migration and Invasion Assays by Boyden Chamber}

Cell migration and invasion were evaluated with the CytoSelect ${ }^{\mathrm{TM}}$ 24-well cell migration assay (Cell Biolabs, San Diego, CA, USA) and BioCoat ${ }^{\mathrm{TM}}$ Matrigel $^{\mathrm{TM}}$ Invasion Chamber (BD Biosciences), respectively. To determine the effect of BSE on cell migration, $2 \times 10^{5}$ lung cancer cells with 0,10 and $20 \mu \mathrm{g} / \mathrm{mL}$ BSE in $200 \mu \mathrm{L}$ serum-free medium were placed on a polycarbonate membrane insert ( $8 \mu \mathrm{m}$ pore size), and then put this insert on the bottom chamber which was filled with DMEM or RPMI-1640 medium containing 10\% FBS as a chemo-attractant. After incubation at $37^{\circ} \mathrm{C}$ for $24 \mathrm{~h}$, the non-migratory cells in the upper chamber were wiped away by scrubbing with wet cotton-tipped swabs for 2-3 times. The invaded cells were fixed with methanol, stained with crystal violet, photographed and counted under a phase-contrast microscope $(400 \times$, Nikon Eclipse TS100, Chiyoda-ku, Tokyo, Japan). The similar procedure was carried out in experiments on cell invasion, except that the polycarbonate membrane was coated with a uniform layer of collagen. 


\subsection{Western Blot Analysis}

To analyze the related proteins, $1.5 \times 10^{6}$ cells were seeded into $10 \mathrm{~cm}$ culture dish with or without BSE treatment. After $24 \mathrm{~h}$ incubation, the medium was removed and cells were washed several times with PBS (0.01 M, pH 7.2). Whole-cell lysates were prepared as our previous paper [53]. The harvested protein concentration was measured using a protein assay kit (Bio-Rad). Samples with equal amounts of denatured proteins were resolved on $10 \%$ sodium dodecyl sulfate polyacrylamide gel electrophoresis (SDS-PAGE). Proteins were transferred onto a nitrocellulose membrane (Immunobilin P; Millipore, Billerica, MA, USA). The membrane was blocked with 5\% nonfat milk in Tris-buffered saline, probed with indicated primary antibody and then hybridized with horseradish peroxidase-conjugated secondary antibodies. The protein levels were detected using Enhanced Chemiluminescence (ECL) Plus Western blotting detection reagents (Amersham Bioscience, Uppsala, Sweden). Densitometric analyses were conducted by ChemiDoc ${ }^{\mathrm{TM}}$ XRS+ System (Bio-Rad).

\subsection{Gas Chromatography-Mass Spectrometry}

GC-MS analysis was performed using Clarus 500 GC and Clarus 500 system (Perkin Elmer, San Diego, CA, USA) with the electron impact mode $(70 \mathrm{eV})$ injector. The GC column was ZB-5 capillary column $\left(30 \mathrm{~m} \times 0.25 \mathrm{~mm}\right.$, film thickness $0.1 \mu \mathrm{m}$, FactorFour ${ }^{\mathrm{TM}}$, Phenomenex, Torrance, CA, USA). Injector temperature was set at $150{ }^{\circ} \mathrm{C}$. Oven temperature was kept at $55^{\circ} \mathrm{C}$ for $5 \mathrm{~min}$, then raised to $300{ }^{\circ} \mathrm{C}$ by a rate of $5^{\circ} \mathrm{C} / \mathrm{min}$, and kept for $10 \mathrm{~min}$. The carrier gas was helium at a flow rate of $1 \mathrm{~mL} / \mathrm{min}$. Diluted samples of $1.0 \mu \mathrm{L}$ were injected manually and the split ratio was 1:5. The percentages of the compounds were calculated by the area normalization method without considering response factors. The components were identified by comparison of their mass spectra with the NIST MS 2.0 database (NIST, Gaithersburg, MD, USA). Four authentic compounds used to confirm the MS-identified ingredients and used in the cytotoxicity experiment on lung cancer cells were purchased from Sigma-Aldrich.

\subsection{Statistical Analysis}

All experiments were carried out for three to five independent replicates. The experimental data were analyzed by Microsoft Excel software (2010, Microsoft Software Inc., Redmond, WA, USA). The data are expressed in terms of mean and standard deviation. The statistical differences were analyzed by Student's t-test.

\section{Conclusions}

This study demonstrates that the supercritical fluid extract of BS (BSE) had significant cytotoxicity on A549 and H661 lung cancer cells. Under BSE treatment, the cell cycle arrest, necrosis by annexin V-FITC/PI double staining detection, and expressions of necroptotic proteins in cancer cells were investigated. These results indicate that BSE exhibited necroptotic effect on NSCLC cells. Additionally, BSE had significant suppressive effects on the migration and invasion of lung cancer cells. The experimental data of chemical composition analysis and the bioactivity assay indicate that $\alpha$-guaiene, $(-)$-guaiol and $\beta$-caryophyllene were mostly responsible for the anti-cancer activity of BSE. In comparison to the aforementioned literature of the aqBSE, the main ingredients of BSE were quite different from those of aqBSE. This might result in the different cell death types (necroptosis vs apoptosis) and their cytotoxicities. Since BSE is prepared by SFE, which is an environment-friendly and efficient technique, as well as possesses a high cytotoxicity toward NSCLC cells, BSE represents a potential source for the treatment of lung cancer.

Author Contributions: All authors contributed to this study. H.-L.W., C.-C.C., M.-T.L., C.-P.W., S.-W.W. and J.-Y.H. conceived and designed the experiments. H.-L.W., J.-C.C., L.-W.F., L.-C.L. and H.-F.H. performed the experiments and analyzed the data. J.-F.Y. and P.-C.H. contributed analysis tools. L.-W.F., C.-C.C., and J.-Y.H. prepared the manuscript. All the authors approved the final version of the paper. 
Funding: The authors gratefully acknowledge the financial support of E-Da Hospital, Taiwan (EDAHP105002), I-Shou University (ISU-106-IUC-01) and the Ministry of Science and Technology of Taiwan (MOST 104-2221-E-214-046).

Conflicts of Interest: The authors declare no conflict of interest.

\section{References}

1. Cho, J.H. Immunotherapy for non-small-cell lung cancer: Current status and future obstacles. Immune Netw. 2017, 17, 378-391. [CrossRef] [PubMed]

2. Langley, R.R.; Fidler, I.J. The seed and soil hypothesis revisited the role of tumor-stroma interactions in metastasis to different organs. Int. J. Cancer 2011, 128, 2527-2535. [CrossRef] [PubMed]

3. Malhotra, J.; Jabbour, S.K.; Aisner, J. Current state of immunotherapy for non-small cell lung cancer. Transl. Lung Cancer Res. 2017, 6, 196-211. [CrossRef] [PubMed]

4. Christofferson, D.E.; Yuan, J. Necroptosis as an alternative form of programmed cell death. Curr. Opin. Cell. Biol. 2010, 22, 263-268. [CrossRef] [PubMed]

5. Galluzzi, L.; Kepp, O.; Kroemer, G. RIP kinases initiate programmed necrosis. J. Mol. Cell. Biol. 2009, 1, 8-10. [CrossRef] [PubMed]

6. Degterev, A.; Huang, Z.; Boyce, M.; Li, Y.; Jagtap, P.; Mizushima, N.; Cuny, G.D.; Mitchison, T.J.; Moskowitz, M.A.; Yuan, J. Chemical inhibitor of nonapoptotic cell death with therapeutic potential for ischemic brain injury. Nat. Chem. Biol. 2005, 1, 112-119. [CrossRef] [PubMed]

7. Rosenbaum, D.M.; Degterev, A.; David, J.; Rosenbaum, P.S.; Roth, S.; Grotta, J.C.; Cuny, G.D.; Yuan, J.; Savitz, S.I. Necroptosis, a novel form of caspase-independent cell death, contributes to neuronal damage in a retinal ischemia-reperfusion injury model. J. Neurosci. Res. 2010, 88, 1569-1576. [CrossRef]

8. Smith, C.C.; Davidson, S.M.; Lim, S.Y.; Simpkin, J.C.; Hothersall, J.S.; Yellon, D.M. Necrostatin: A potentially novel cardioprotective agent? Cardiovasc. Drugs Ther. 2007, 21, 227-233. [CrossRef]

9. Huang, C.; Luo, Y.; Zhao, J.; Yang, F.; Zhao, H.; Fan, W.; Ge, P. Shikonin kills glioma cells through necroptosis mediated by RIP-1. PLoS ONE 2013, 8, e66326. [CrossRef]

10. Wu, M.; Jiang, Z.; Duan, H.; Sun, L.; Zhang, S.; Chen, M.; Wang, Y.; Gao, Q.; Song, Y.; Zhu, X.; et al. Deoxypodophyllotoxin triggers necroptosis in human non-small cell lung cancer NCI-H460 cells. Biomed. Pharmacother. 2013, 67, 701-706. [CrossRef]

11. Yan, C.; Oh, J.S.; Yoo, S.H.; Lee, J.S.; Yoon, Y.G.; Oh, Y.J.; Jang, M.S.; Lee, S.Y.; Yang, J.; Lee, S.H.; et al. The targeted inhibition of mitochondrial Hsp90 overcomes the apoptosis resistance conferred by Bcl-2 in Hep3B cells via necroptosis. Toxicol. Appl. Pharmacol. 2013, 266, 9-18. [CrossRef] [PubMed]

12. Krysko, O.; Aaes, T.L.; Kagan, V.E.; D’Herde, K.; Bachert, C.; Leybaert, L.; Vandenabeele, P.; Krysko, D.V. Necroptotic cell death in anti-cancer therapy. Immunol. Rev. 2017, 280, 207-219. [CrossRef] [PubMed]

13. Seifert, L.; Miller, G. Molecular pathways: The necrosome-A target for cancer therapy. Clin. Cancer Res. 2017, 23, 1132-1136. [CrossRef] [PubMed]

14. Fidler, I.J. The organ microenvironment and cancer metastasis. Differentiation 2005, 70, 498-505. [CrossRef] [PubMed]

15. Arvelo, F.; Cotte, C. Metalloproteinases in tumor progression. Review. Investig. Clin. 2006, 47, $185-205$. [PubMed]

16. Imanaka, H.H.; Koide, K.; Shimizu, T.; Asai, N.; Kinouchi Shimizu, A.; Ishikado, T.; Makino, N.O. Chemoprevention of tumor metastasis by liposomal $\beta$-sitosterol intake. Biol. Pharm. Bull. 2008, 31, 400-404. [CrossRef] [PubMed]

17. Gordaliza, M.P.A.; Garcia, J.M.; del Corral, M.A.; Castro Gomez-Zurita, M.A. Podophyllotoxin: Distribution, sources, applications and new cytotoxic derivatives. Toxicon 2004, 44, 441-459. [CrossRef]

18. Liu, Y.Q.; Tian, J.; Qian, K.; Zhao, X.B.; Morris-Natschke, S.L.; Yang, L.; Nan, X.; Tian, X.; Lee, K.H. Recent progress on C-4-modified podophyllotoxin analogs as potent antitumor agents. Med. Res. Rev. 2015, 35, 1-62. [CrossRef]

19. Stage, T.B.; Bergmann, T.K.; Kroetz, D.L. Clinical pharmacokinetics of paclitaxel monotherapy: An updated literature review. Clin. Pharmacokinet. 2018, 57, 7-19. [CrossRef] 
20. Cazzaniga, M.E.; Camerini, A.; Addeo, R.; Nolè, F.; Munzone, E.; Collovà, E.; Del Conte, A.; Mencoboni, M.; Papaldo, P.; Pasini, F.; et al. Metronomic oral vinorelbine in advanced breast cancer and non-small-cell lung cancer: Current status and future development. Future Oncol. 2016, 12, 373-387. [CrossRef]

21. Venditto, V.J.; Simanek, E.E. Cancer therapies utilizing the camptothecins: A review of in vivo literature. Mol. Pharm. 2010, 7, 307-349. [CrossRef] [PubMed]

22. Li, N.; He, Y.; Wang, L.; Mo, C.; Zhang, J.; Zhang, W. D-Galactose induces necroptotic cell death in neuroblastoma cell lines. J. Cell. Biochem. 2011, 112, 3834-3844. [CrossRef] [PubMed]

23. Pasupuleti, N.; Leon, L.; Carraway, K.L.; Gorin, F. 5-Benzylglycinyl-amiloride kills proliferating and nonproliferating malignant glioma cells through caspase-independent necroptosis mediated by apoptosis-inducing factor. J. Pharmacol. Exp. Ther. 2013, 344, 600-615. [CrossRef] [PubMed]

24. Basit, F.; Cristofanon, S.; Fulda, S. Obatoclax (GX15-070) triggers necroptosis by promoting the assembly of the necrosome on autophagosomal membranes. Cell. Death Differ. 2013, 20, 1161-1173. [CrossRef]

25. Sun, W.; Bao, J.; Lin, W.; Gao, H.; Zhao, W.; Zhang, Q.; Leung, C.H.; Ma, D.L.; Lu, J.; Chen, X. 2-Methoxy-6-acetyl7-methyljuglone (MAM), a natural naphthoquinone, induces NO-dependent apoptosis and necroptosis by $\mathrm{H}_{2} \mathrm{O}_{2}$-dependent JNK activation in cancer cells. Free Radic. Biol. Med. 2016, 92, 61-77. [CrossRef]

26. Jing, L.; Song, F.; Liu, Z.; Li, J.; Wu, B.; Fu, Z.; Jiang, J.; Chen, Z. MLKL-PITP $\alpha$ signaling-mediated necroptosis contributes to cisplatin-triggered cell death in lung cancer A549 cells. Cancer Lett. 2018, 414, 136-146. [CrossRef]

27. Han, W.; Li, L.; Qiu, S.; Lu, Q.; Pan, Q.; Gu, Y. Shikonin circumvents cancer drug resistance by induction of a necroptotic death. Mol. Cancer Ther. 2007, 6, 1641-1649. [CrossRef]

28. Xuan, Y.; Hu, X. Naturally-occurring shikonin analogues-A class of necroptotic inducers that circumvent cancer drug resistance. Cancer Lett. 2009, 274, 233-242. [CrossRef]

29. Fu, Z.; Deng, B.; Liao, Y.; Shan, L.; Yin, F.; Wang, Z. The anti-tumor effect of shikonin on osteosarcoma by inducing RIP1 and RIP3 dependent necroptosis. BMC Cancer 2013, 13, 580. [CrossRef]

30. Wada, N.; Kawano, Y.; Fujiwara, S.; Kikukawa, Y.; Okuno, Y.; Tasaki, M.; Ueda, M.; Ando, Y.; Yoshinaga, K.; $\mathrm{Ri}$, M.; et al. Shikonin dually functions as a proteasome inhibitor and a necroptosis inducer in multiple myeloma cells. Int. J. Oncol. 2015, 46, 963-972. [CrossRef]

31. Li, S.; Zhang, T.; Xu, W.; Ding, J.; Yin, F.; Xu, J.; Sun, W.; Wang, H.; Sun, M.; Cai, Z.; et al. Sarcoma-targeting peptide-decorated polypeptide nanogel intracellularly delivers shikonin for upregulated osteosarcoma necroptosis and diminished pulmonary metastasis. Theranostics 2018, 8, 1361-1375. [CrossRef] [PubMed]

32. Uquiche, E.; Cirano, N.; Millao, S. Supercritical fluid extraction of essential oil from Leptocarpha rivularis using $\mathrm{CO}_{2}$. Ind. Crops Prod. 2015, 77, 307-314. [CrossRef]

33. Rai, A.; Bhargava, R.; Mohanty, B. Simulation of supercritical fluid extraction of essential oil from natural products. J. Appl. Res. Med. Aromat. Plants 2017, 5, 1-9. [CrossRef]

34. Priyanka, S.K. Influence of operating parameters on supercritical fluid extraction of essential oil from turmeric root. J. Clean. Prod. 2018, 188, 816-824. [CrossRef]

35. Rodilla, J.M.; Silva, L.A.; Martinez, N.; Lorenzo, D.; Davyt, D.; Castillo, L.; Giménez, C.; Cabrera, R.; González-Coloma, A.; Zrostlíková, J.; et al. Advances in the identification and agrochemical importance of sesquiterpenoids from Bulnesia sarmientoi essential oil. Ind. Crops Prod. 2011, 33, 497-503. [CrossRef]

36. Hiebert, M.R.; Flores-Giubi, M.E.; Barua, J.E.; Molina-Salinas, G.M.; Ferro, E.A.; Alvarenga, N.L. Antimycobacterial activity of the ethanolic extract of the wood of Bulnesia Sarmientoi Lorentz Ex. Griseb. Rev. Latinoamer. Quím. 2012, 40,7-12.

37. Kamruzzaman, S.M.; Endale, M.; Oh, W.J.; Park, S.C.; Kim, K.S.; Hong, J.H.; Kwak, Y.S.; Yun, B.S.; Rhee, M.H. Inhibitory effects of Bulnesia sarmienti aqueous extract on agonist-induced platelet activation and thrombus formation involves mitogen-activated protein kinases. J. Ethnopharmacol. 2010, 130, 614-620. [CrossRef]

38. Mollah, M.L.; Kim, J.O.; Lee, G.D.; Park, C.H.; Hong, J.H.; Kim, H.Y.; Kim, K.S. Growth-inhibitory effects of a Bulnesia sarmienti aqueous extract on A549 cells in vitro and S180 cells in vivo. Immunopharmacol. Immunotoxicol. 2009, 31, 492-498. [CrossRef]

39. Mollah, M.L.; Song, J.C.; Park, C.H.; Lee, G.D.; Hong, J.H.; Ryoo, Z.Y.; Lee, S.; Chang, K.T.; Kim, K.S. Anticancer activity and apoptotic effects of Bulnesia sarmienti against human lung cancer H460 cells. Oncol. Res. 2009, 18, 259-267. [CrossRef]

40. Kim, D.; Mollah, M.L.; Kim, K. Induction of apoptosis of SW480 human colon cancer cells by (-)-epicatechin isolated from Bulnesia sarmienti. Anticancer Res. 2012, 32, 5353-5361. [PubMed] 
41. Wu, W.; Liu, P.; Li, J. Necroptosis: An emerging form of programmed cell death. Crit. Rev. Oncol. Hematol. 2012, 82, 249-258. [CrossRef] [PubMed]

42. Jouan-Lanhouet, S.; Arshad, M.; Piquet-Pellorce, C.; Martin-Chouly, C.; Le Moigne-Muller, G.; Van Herreweghe, F. TRAIL induces necroptosis involving RIPK1/RIPK3-dependent PARP-1 activation. Cell. Death Differ. 2012, 19, 2003-2014. [CrossRef] [PubMed]

43. Vanlangenakker, N.; Vanden Berghe, T.; Vandenabeele, P. Many stimuli pull the necrotic trigger, an overview. Cell. Death Differ. 2012, 19, 75-86. [CrossRef] [PubMed]

44. Huang, A.C.; Sefton, M.A.; Sumby, C.J.; Tiekink, E.R.; Taylor, D.K. Mechanistic studies on the autoxidation of $\alpha$-guaiene: Structural diversity of the sesquiterpenoid downstream products. J. Nat. Prod. 2015, 78, 131-145. [CrossRef] [PubMed]

45. Silva-Filho, S.E.; Wiirzler, L.A.M.; Cavalcante, H.A.O.; Uchida, N.S.; de Souza Silva-Comar, F.M.; Cardia, G.F.E.; da Silva, E.L.; Aguiar, R.P.; Bersani-Amado, C.A.; Cuman, R.K.N. Effect of patchouli (Pogostemon cablin) essential oil on in vitro and in vivo leukocytes behavior in acute inflammatory response. Biomed. Pharmacother. 2016, 84, 1697-1704. [CrossRef] [PubMed]

46. Zhang, H.Y.; Gao, Y.; Lai, P.X. Chemical composition, antioxidant, antimicrobial and cytotoxic activities of essential oil from Premna microphylla Turczaninow. Molecules 2017, 22, 381. [CrossRef] [PubMed]

47. De Alencar, D.C.; Pinheiro, M.L.; Pereira, J.L.; de Carvalho, J.E.; Campos, F.R.; Serain, A.F.; Tirico, R.B.; Hernández-Tasco, A.J.; Costa, E.V.; Salvador, M. Chemical composition of the essential oil from the leaves of Anaxagorea brevipes (Annonaceae) and evaluation of its bioactivity. Nat. Prod. Res. 2016, 30, 1088-1092. [CrossRef]

48. Shu, Z.; Pu, J.; Chen, L.; Zhang, Y.; Rahman, K.; Qin, L.; Zheng, C. Alisma orientale: Ethnopharmacology, phytochemistry and pharmacology of an important traditional Chinese mdicine. Am. J. Chin. Med. 2016, 44, 227-251. [CrossRef] [PubMed]

49. Yang, Q.; Wu, J.; Luo, Y.; Huang, N.; Zhen, N.; Zhou, Y.; Sun, F.; Li, Z.; Pan, Q.; Li, Y. (-)-Guaiol regulates RAD51 stability via autophagy to induce cell apoptosis in non-small cell lung cancer. Oncotarget 2016, 7, 62585-62597. [CrossRef] [PubMed]

50. Yang, X.; Zhu, J.; Wu, J.; Huang, N.; Cui, Z.; Luo, Y.; Sun, F.; Pan, Q.; Li, Y.; Yang, Q. (-)-Guaiol regulates autophagic cell death depending on mTOR signaling in NSCLC. Cancer Biol. Ther. 2018, 19, 706-714. [CrossRef] [PubMed]

51. Dahham, S.S.; Tabana, Y.M.; Iqbal, M.A.; Ahamed, M.B.; Ezzat, M.O.; Majid, A.S.; Majid, A.M. The anticancer, antioxidant and antimicrobial properties of the sesquiterpene $\beta$-caryophyllene from the essential oil of Aquilaria crassna. Molecules 2015, 20, 11808-11829. [CrossRef] [PubMed]

52. Selestino Neta, M.C.; Vittorazzi, C.; Guimarães, A.C.; Martins, J.D.; Fronza, M.; Endringer, D.C.; Scherer, R. Effects of $\beta$-caryophyllene and Murraya paniculata essential oil in the murine hepatoma cells and in the bacteria and fungi 24-h time-kill curve studies. Pharm. Biol. 2017, 55, 190-197. [CrossRef] [PubMed]

53. Chang, C.C.; Hsu, H.F.; Huang, K.H.; Wu, J.M.; Kuo, S.M.; Ling, X.H.; Houng, J.Y. Anti-proliferative effects of Siegesbeckia orientalis ethanol extract on human endometrial RL-95 cancer cells. Molecules 2014, 19, 19980-19994. [CrossRef] [PubMed]

54. Pavithra, P.S.; Mehta, A.; Verma, R.S. Synergistic interaction of $\beta$-caryophyllene with aromadendrene oxide 2 and phytol induces apoptosis on skin epidermoid cancer cells. Phytomedicine 2018, 47, 121-134. [CrossRef] [PubMed]

Sample Availability: Not available. 